\section{Adenosine Triphosphate-dependent Calcium Pump in the Plasma Membrane of Guinea Pig and Human Neutrophils}

Hjalmar Lagast, P. Daniel Lew, and Francis A. Waldvogel Division of Infectious Diseases, Department of Medicine, Hôpital Cantonal Universitaire, Geneva, Switzerland bstract. Changes in cytosolic free $\mathrm{Ca}$ may function as a second messenger in neutrophils. Since the plasma membrane seems to be a major regulator of intracellular $\mathrm{Ca}$ in many cells, we characterized an energydependent $\mathrm{Ca}$ transport system in plasma membraneenriched fractions ("podosomes") from phorbol myristate acetate-stimulated guinea pig and human neutrophils. The active $\mathrm{Ca}$ transport system in guinea pig podosomes exhibited a high affinity for $\mathrm{Ca}$ (Michaelis constant $\left[K_{\mathrm{m}}\right] \mathrm{Ca}$ $280 \pm 120 \mathrm{nM}$ ) and a maximum velocity of $0.83 \mathrm{nmol}$ $\mathrm{Ca} / \mathrm{mg}$ protein per min. Uptake showed an absolute requirement for Mg ATP $\left(K_{\mathrm{m}}\right.$ ATP $\left.67 \mu \mathrm{M}\right)$, whereas other trinucleotides were inactive. $\mathrm{Ca}$ uptake was optimal at pH 7, was azide insensitive and temperature dependent. Vanadium, an inhibitor of the $\mathrm{Ca} / \mathrm{Mg}$ ATPase of heart sarcolemma, inhibited Ca pump activity by $50 \%$ at $1 \mu \mathrm{M}$. $\mathrm{Ca}$ transport was not affected in a $\mathrm{NaCl}$-containing medium, an observation arguing against the presence of a $\mathrm{Na} / \mathrm{Ca}$ exchange system. Calmodulin at $0.5-10 \mu \mathrm{g} / \mathrm{ml}$ stimulated the Ca pumping activity of EGTA-washed podosomes. Calmodulin depletion decreased the affinity of the Ca pump for $\mathrm{Ca}\left(K_{\mathrm{m}} \mathrm{Ca} 2.07 \mu \mathrm{M}\right)$ and its readdition restored it $\left(K_{\mathrm{m}} \mathrm{Ca} 0.55 \mu \mathrm{M}\right)$.

ATP-dependent $\mathrm{Ca}$ transport by podosomes and

This work was presented in part at the National Meeting of the American Federation for Clinical Research, Washington DC, 29 April-2 May 1983 and was published in abstract form in Clin. Res. 1983. 31(2):369A.

Dr. Lagast is the recipient of a fellowship from the Foundation Jean and Rose Hoguet, Brussels, Belgium; his present address is Service de Médecine Interne, Institut Jules Bordet, Brussels, Belgium. Dr. Lew is the recipient of a Max Cloetta career development award.

Received for publication 30 June 1983 and in revised form 20 September 1983.

J. Clin. Invest.

(C) The American Society for Clinical Investigation, Inc.

0021-9738/84/01/0107/09 \$1.00

Volume 73, January $1984,107-115$ phagocytic vesicles was inactivated by exposure to trypsin or to the nonpenetrating sulfhydryl reagent $p$-chloromercuribenzene sulfonate. Human podosomes had a $\mathrm{Ca}$ uptake system with properties similar to those of the guinea pig.

These findings demonstrate the presence of a Ca pump in the neutrophil plasma membrane, which is active at physiological concentrations of free cytosolic Ca. By changing $\mathrm{Ca}$ concentrations at the cell periphery, this pump could control various motile functions of the neutrophil, such as locomotion or degranulation.

\section{Introduction}

Polymorphonuclear leukocytes (PMN), the first line of defense against invading microorganisms, are highly motile cells, which also produce toxic oxygen metabolites such as superoxide and hydrogen peroxide and release granular enzymes that kill bacteria, fungi, and parasites (1-3). The intracellular mechanisms modulating and synchronizing these various PMN functions are largely unknown.

There is increasing evidence that the intracellular concentration of ionized Ca may play a crucial role in modulating the activity of PMN, for example, the stimulation of the cell by $\mathrm{Ca}^{2+}$ ionophores (4-7) and the inhibition of cell function by $\mathrm{Ca}^{2+}$ antagonists (8-11). Intracellular Ca-binding proteins such as gelsolin and calmodulin seem to be implicated in the regulation of PMN movement and metabolism. Therefore, it becomes important to understand how phagocytes are capable of controlling their levels of intracellular $\mathrm{Ca}$. In particular, $\mathrm{Ca}$ movements across the plasma membrane could be of great physiologic importance, since membrane receptor activation immediately generates a series of events, including changes in cytosolic free Ca concentration (14-16).

By using a plasma membrane-enriched fraction that contains a subpopulation of inside-out vesicles, we demonstrated that PMN have a calcium transport system that pumps $\mathrm{Ca}$ from the cytoplasm to the external surface of the membrane. A detailed examination of this energy-dependent Ca pump forms the basis of this report. 


\section{Methods}

Chemicals. Ruthenium red and $N$-ethylmaleimide (NEM) ${ }^{1}$ were obtained from Aldrich-Europe, Beerse, Belgium; Ionophore A23187 from Calbiochem-Behring Corp., American Hoechst Corp., San Diego, CA. ADP, cytosine triphosphate (CTP), diisopropylfluorophosphate (DFP), EGTA, guanosine triphosphate (GTP), inosine triphosphate (ITP), catalase, soybean trypsin inhibitor (SBTI), phorbol myristate acetate (PMA), p-chloromercuribenzene sulfonic acid (pCMBS), uridine triphosphate (UTP), trypsin type IX, and ouabain were obtained from Sigma Chemical Co., St. Louis, MO. Sodium caseinate and lipopolysaccharide B were purchased from Difco Laboratories, Detroit, MI. Triton X-100 and phenylmethylsulfonylfluoride (PMSF) were purchased from Merck, AG, Darmstadt, Federal Republic of Germany; sodium orthovanadate from Fisher Scientific Co., Pittsburgh, PA. Aquasol and ${ }^{45} \mathrm{Ca}\left(\right.$ as $\left.\mathrm{CaCl}_{2}\right)$ were obtained from New England Nuclear, Boston, MA. Calmodulin was prepared from bovine brain as described previously (17).

Guinea pig neutrophils. $20 \mathrm{ml}$ of a $12 \%$ solution of sodium caseinate in saline was injected intraperitoneally into guinea pigs (18). 14-16 h later, the animals were killed and the peritoneal cavity was opened and washed with isotonic saline. The lavage fluid containing the harvested cells was filtered through a sterile gauze. These cells were washed three times by centrifugation at $4^{\circ} \mathrm{C}(250 \mathrm{~g}, 10 \mathrm{~min})$ and finally resuspended in phosphate-buffered saline (PBS) $(130 \mathrm{mM} \mathrm{NaCl}, 4 \mathrm{mM} \mathrm{KCl}, 10 \mathrm{mM}$ sodium-phosphate buffer, $\mathrm{pH}$ 7.4) supplemented with $5 \mathrm{mM}$ glucose, and kept at $0^{\circ} \mathrm{C}$ until used. Yields ranged from $7 \times 10^{8}$ to $1.5 \times 10^{9}$ PMN cells/guinea pig, representing $>90 \%$ of the harvested cells. Cell viability was assessed by trypan blue exclusion.

Human neutrophils. Peripheral blood granulocytes were collected from healthy donors in acid-citrate-dextrose and purified by dextran and Ficoll-Hypaque sedimentation as described by Böyum (19). Erythrocytes were removed by hypotonic lysis. The cells, of which $>95 \%$ were PMN, were washed, suspended in PBS supplemented with glucose, and kept at $4^{\circ} \mathrm{C}$ until used.

Sera. Guinea pig serum was obtained from freshly clotted blood after cardiac puncture of anesthetized animals. Sera were used on the same day or stored at $-70^{\circ} \mathrm{C}$ until used.

Preparation of neutrophil plasma membrane-enriched vesicles (podosomes). Plasma membrane-enriched vesicles were prepared as described previously $(20,21)$. The preparation, which is virtually free of organelles, is a mixture of right-side-out and inside-out "blebs." Both human peripheral or guinea pig exudate PMN were used. PMN $\left(2 \times 10^{8}\right.$ in $5 \mathrm{ml}$ ) were incubated at $37^{\circ} \mathrm{C}$ in glass conical centrifuge tubes in the presence of $1 \mu \mathrm{g} / \mathrm{ml}$ of PMA in PBS with glucose for $5 \mathrm{~min}$. After incubation, the suspension was placed in a sonication bath at $37^{\circ} \mathrm{C}$ for 8-10 s, then placed in an ice bath. The samples were centrifuged at 250 $g$ for $10 \mathrm{~min}$ to allow the residual cell bodies to sediment. The resulting cloudy supernatant was centrifuged at $10,000 \mathrm{~g}$ for $10 \mathrm{~min}$. The pellet was washed in a solution containing $250 \mathrm{mM}$ sucrose- $30 \mathrm{mM}$ imidazole$\mathrm{HCl}, \mathrm{pH} \mathrm{7,} \mathrm{resuspended} \mathrm{in} \mathrm{the} \mathrm{same} \mathrm{solution,} \mathrm{and} \mathrm{kept} \mathrm{on} \mathrm{ice} \mathrm{until}$ used.

A Ca transport system can be demonstrated in podosomes prepared in the absence of PMA. Nevertheless, we elected to characterize the $\mathrm{Ca}$

1. Abbreviations used in this paper: CTP, cytosine triphosphate; DFP, diisopropylfluorophosphate; DMSO, dimethyl sulfoxide; GTP, guanosine triphosphate; ITP, inosine triphosphate; NEM, $N$-ethylmaleimide; pCMBS, $p$-chloromercuribenzene sulfonic acid; PMA, phorbol myristate acetate; PMSF, phenylmethylsulfonylfluoride; SBTI, soybean trypsin inhibitor; UTP, uridine triphosphate. pump of podosomes prepared in the presence of this phorbol ester, because PMA activates the NADPH-dependent superoxide generating system (22). This would allow the simultaneous study of both the Ca transport and superoxide generating systems.

The Ca transport activity of human podosomes was more labile than that obtained from guinea pig neutrophils. The activity of human podosomes stored at $0^{\circ} \mathrm{C}$ decreased rapidly to $\sim 30 \%$ after $2 \mathrm{~h}$ in contrast to guinea pig podosomes where the activity was stable $2 \mathrm{~h}$ after preparation. When the sonication of human PMN was performed in the presence of PMSF $(5 \mathrm{mM})$ and catalase $(10,000 \mathrm{U} / \mathrm{ml})$, loss of activity was decreased.

To obtain an estimate of the proportion of inside-out vesicles in podosomes, we measured the activity of 5'-nucleotidase, an ectoenzyme of guinea pig neutrophils, in this fraction, in the absence and presence of $0.1 \%$ Triton X-100. The proportion of inside-out vesicles was calculated as described for erythrocytes $(23,24)$ :

$$
\% \text { Inside-out vesicles }=\left[1-\frac{\text { normal }}{\text { Triton X-100 }}\right] \times 100 \text {. }
$$

Preparation of phagocytic vesicles. This technique, described in detail elsewhere (25), is outlined briefly below. Diisododecylphthalate (1 ml) (practical grade; Matheson, Coleman and Bell, E. Rutherford, $\mathrm{NJ}$ ) was added to $3 \mathrm{ml}$ of medium containing lipopolysaccharide B from Escherichia coli 026: B6 at a final concentration of $10 \mathrm{mg} / \mathrm{ml}$, and the suspension was sonicated for $90 \mathrm{~s}$ to form oil droplets coated with lipopolysaccharide.

Lipopolysaccharide particles were incubated with fresh or freshly thawed guinea pig serum for $20 \mathrm{~min}$ at $37^{\circ} \mathrm{C}$, during which time an opsonic fragment of the third component of complement interacts with them (opsonized particles) (26). Cells were suspended in Krebs-Ringer's phosphate medium ( $130 \mathrm{mM} \mathrm{NaCl}, 4 \mathrm{mM} \mathrm{KCl}, 1.3 \mathrm{mM} \mathrm{MgCl}, 1 \mathrm{mM}$

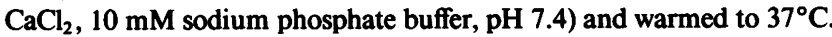
Suspensions of opsonized particles $(20 \%$, vol/vol) and cells $(5 \%$, vol/ vol) were mixed and agitated gently in a shaking bath at $37^{\circ} \mathrm{C}$ for 5 min.

The cells were incubated with $5 \mathrm{mM}$ DFP for $5 \mathrm{~min}$ at $0^{\circ} \mathrm{C}$ to inhibit serine proteases (27). The cells which had ingested opsonized particles were washed once in cold $0.15 \mathrm{M} \mathrm{NaCl}$, suspended in deionized ice-cold water, and immediately centrifuged at $4^{\circ} \mathrm{C}$. Exposure to water caused the cells to swell but not to rupture, and rendered subsequent homogeneization easier to perform.

The cell pellets were suspended in an equal volume of ice-cold 0.34 M sucrose containing $5 \mathrm{mM}$ EGTA, $5 \mathrm{mM}$ dithiothreitol, $30 \mathrm{mM}$ imidazole-HCl buffer, $\mathrm{pH} \mathrm{7.4,} \mathrm{and} \mathrm{several} \mathrm{protease} \mathrm{inhibitors,} \mathrm{including}$ $1 \mathrm{mM} \mathrm{PMSF}, 0.25 \mathrm{mg} / \mathrm{ml}$ of $\alpha$-1-antitrypsin, and $0.25 \mathrm{mg} / \mathrm{ml}$ of SBTI. The cells were homogenized in this medium in a 5-ml Dounce homogenizer with a tight-fitting pestle. Progressive cell rupture was assessed by determining the percentage of intact cells by phase-contrast microscopy. About 25 strokes were required to break $90 \%$ of the cells. Ca $\left(\mathrm{CaCl}_{2}\right)$ was then added to a final concentration of $5 \mathrm{mM}$. Thereafter, the homogenate was transferred to a 30-ml Sorvall centrifuge tube and carefully overlaid by means of a peristaltic pump (Pharmacia Fine Chemicals AB, Uppsala, Sweden) with 2 vol of a solution containing $250 \mathrm{mM}$ sucrose, $30 \mathrm{mM}$ imidazole- $\mathrm{HCl} \mathrm{pH} 7$, and centrifuged for 60 min at $20,000 \mathrm{~g}$. The floating white layer, representing isolated phagocytic vesicles, was then carefully removed and kept at $0^{\circ} \mathrm{C}$ until it was further diluted for use.

Calcium uptake. Ca uptake by phagocytic vesicles or peripheral vesicles of PMN was measured in a "standard" medium containing 100 
$\mathrm{mM} \mathrm{KCl}, 30 \mathrm{mM}$ imidazole- $\mathrm{HCl}$ buffer, $5 \mathrm{mM}$ sodium azide at a $\mathrm{pH}$ of 7 and at various concentrations of $\mathrm{MgCl}_{2}, \mathrm{ATP}$ ( $\mathrm{pH}$ adjusted to 7), and $\mathrm{CaCl}_{2}$ in a total volume of 250 or $500 \mu$ l. Human podosomes were tested in the presence of $2 \mathrm{mM}$ PMSF. The test was carried out as follows: Membrane vesicles at concentrations of $\sim 0.2-0.9 \mathrm{mg}$ of protein/ $\mathrm{ml}$ of medium, were warmed at $37^{\circ} \mathrm{C}$ in the above medium for $5 \mathrm{~min}$. When it was used, $5 \mathrm{mM}$ ammonium oxalate was added 2 min after the membranes. The suspension was mixed and the reaction was started by the addition of $\mathrm{CaCl}_{2}$ (usually $25 \mu \mathrm{M}$ containing $1-10 \mu \mathrm{Ci} / \mathrm{ml}$ of $\left.{ }^{45} \mathrm{Ca}\right)$, followed by quick agitation. Samples $(75 \mu \mathrm{l})$ were taken from the mixture at defined intervals and added to $2 \mathrm{ml}$ of a solution containing $100 \mathrm{mM} \mathrm{KCl}, 30 \mathrm{mM}$ imidazole- $\mathrm{HCl}, \mathrm{pH}$ 7. Vesicles were trapped by vacuum filtration with a manifold (Millipore Corp., Bedford, MA) on $0.45-\mu \mathrm{m}$ pore filters (Millipore Corp.) which were washed with $0.25 \mathrm{M}$ $\mathrm{KCl}(2 \mathrm{ml})$, followed by water $(11 \mathrm{ml})$ before addition of test samples. The filters containing vesicles were washed once with $2 \mathrm{ml}$ of the same $\mathrm{KCl} /$ imidazole- $\mathrm{HCl}$ buffer and were dissolved in Aquasol and counted for ${ }^{45} \mathrm{Ca}$ radioactivity in a scintillation counter (Beckman Instruments Inc., Palo Alto, CA). Ca uptake rates were expressed as nanomoles $\mathrm{Ca}$ per milligram total protein per minute after the values bound in the absence of ATP were subtracted. The calcium ionophore A23187 was dissolved with dimethyl sulfoxide (DMSO) and then diluted with the incubation buffer to a final concentration of $5 \mu \mathrm{M}$. Control experiments were performed to ensure that DMSO at similar concentrations did not alter calcium uptake by the podosomes.

Calculation and measure of free calcium concentration and kinetic parameters. The free Ca concentration of solutions in the presence of ATP and EGTA was calculated initially by means of the computer program of Perrin and Sayce (28) as described previously (17). The Ca content of all buffers, various reactants, and that of the vesicles was determined by atomic absorption and taken into account when calculating free $\mathrm{Ca}$ concentrations. For experiments in which affinity constants for $\mathrm{Ca}$ were determined, final free $\mathrm{Ca}$ concentrations were measured with a Ca-sensitive electrode. Mini-Ca electrodes were prepared using $\mathrm{Ca}-$ selective semiliquid membranes according to Simon et al. (29). The composition of the membrane corresponded to electrode No. 16 shown in Table I of reference 29. A good correlation between calculated and measured free $\mathrm{Ca}$ was found down to $\sim 0.3 \mu \mathrm{M} \mathrm{Ca}$, beyond which the electrodes did not display a linear response any more when in the presence of protein.

Kinetic parameters (Michaelis constant $\left[K_{\mathrm{m}}\right]$ and maximum velocity [ $\left.\left.V_{\max }\right]\right)$ of the Ca transport system were drawn according to the fitting of the data obtained by computer analysis, assuming that a single $\mathrm{Mi}-$ chaelis-Menten component participated in total Ca transport (30).

Special procedures. To detect inhibition of Ca transport by vanadium, pCMBS, NEM, azide, and trypsin, the vesicles were treated as follows. Podosomes were incubated for $10 \mathrm{~min}$ at room temperature and for $5 \mathrm{~min}$ at $37^{\circ} \mathrm{C}$ with the appropriate concentrations of vanadate. Ca uptake was started with the addition of $2.5 \mathrm{mM}$ ATP.

Podosomes or whole PMN were incubated at $0^{\circ} \mathrm{C}$ for 30 min with $50 \mu \mathrm{M}$ pCMBS and washed before further processing. For NEM inhibition the following procedure was carried out (31): Podosomes were preincubated $1 \mathrm{~h}$ at $0^{\circ} \mathrm{C}$ with $5 \mathrm{mM} \mathrm{NEM}$, before performing the Ca uptake. Ruthenium red was added to a standard medium without sodium azide at the same time as podosomes. The effect of sodium azide was studied by comparing $\mathrm{Ca}$ uptake performed in the presence and absence of sodium azide in the standard medium. Trifluoroperazine was added 2 min before starting Ca uptake with $\mathrm{Mg}$ ATP. The trypsinization procedure was performed as previously described (17): Prewarmed trypsin stock solution was added to make a final concentration of $1 \mathrm{mg} / \mathrm{ml}$ to a suspension of podosomes, after $5 \mathrm{~min}$ at $37^{\circ} \mathrm{C}, \mathrm{SBTI}$ was added to a final concentration of $1 \mathrm{mg} / \mathrm{ml}$.

Protein was determined by the method of Lowry by using bovine serum albumin as a standard (32).

Calmodulin activation of calcium uptake into podosomes. These experiments were performed with podosomes suspended in $250 \mathrm{mM}$ sucrose, $30 \mathrm{mM}$ imidazole buffer, $\mathrm{pH} \mathrm{7,} \mathrm{and} \mathrm{incubated} \mathrm{for} 5 \mathrm{~min}$ at $0^{\circ} \mathrm{C}$ with $1 \mathrm{mM}$ DFP and $2 \mathrm{mM}$ EGTA. The podosomes were then washed in the sucrose-imidazole buffer $(10,000 \mathrm{~g}, 10 \mathrm{~min})$, resuspended in the sucrose-imidazole with $1 \mathrm{mM}$ EGTA but without DFP. They were centrifuged again $(10,000 \mathrm{~g}, 10 \mathrm{~min})$, resuspended in the sucroseimidazole buffer, and kept at $0^{\circ} \mathrm{C}$ until used. The aim of these two EGTA washes was to remove calmodulin bound to inside-out vesicles $(33,34)$. This preparation was sensitive to the extrinsic addition of bovine brain calmodulin (see below). The washed podosome preparation was incubated with various concentrations of bovine brain calmodulin for $5 \mathrm{~min}$ at $0^{\circ} \mathrm{C}$, with occasional agitation in the standard medium, then warmed for $5 \mathrm{~min}$ at $37^{\circ} \mathrm{C}$ before starting the reaction with Mg ATP.

\section{Results}

Uptake of calcium by podosomes. Fig. 1 shows a time course of Ca uptake by podosomes obtained from guinea pig PMN. To understand the following results, it is important to note that in our study only inside-out membranes were active (as demonstrated below), and that calcium was therefore pumped into the vesicles (called "uptake"), as opposed to the situation in intact PMN, where $\mathrm{Ca}$ is extruded from the cytoplasm into the extracellular medium. In the absence of ATP or $\mathrm{MgCl}_{2}, \sim 0.5$ $\mathrm{nmol} \mathrm{Ca} / \mathrm{mg}$ protein became associated with the podosomes in

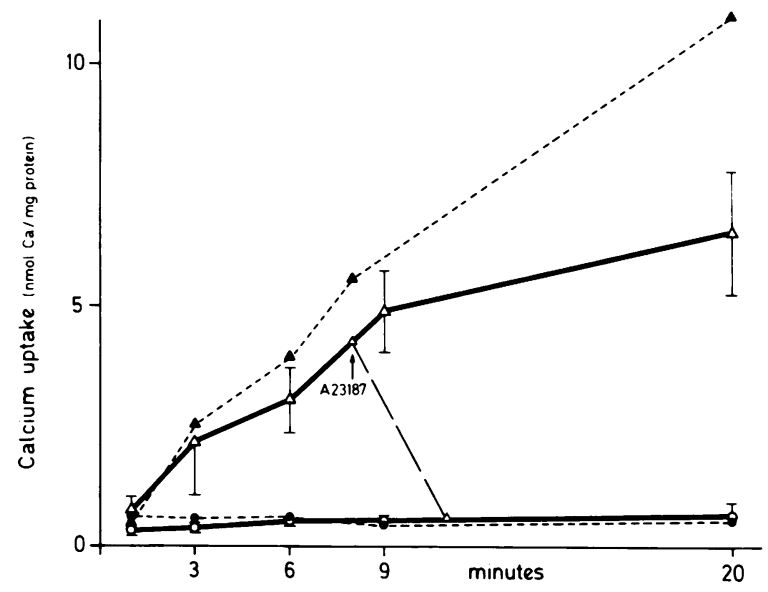

Figure 1. Calcium uptake by podosomes from guinea pig PMN. Ca uptake was measured in the following medium: $100 \mathrm{mM} \mathrm{KCl}, 30$ $\mathrm{mM}$ imidazole- $\mathrm{HCl}$ buffer, $\mathrm{pH} 7,5 \mathrm{mM}$ sodium azide, $25 \mu \mathrm{M} \mathrm{CaCl}_{2}$, $10 \mu \mathrm{Ci}{ }^{45} \mathrm{CaCl}_{2} / \mathrm{ml}$ in a total volume of $500 \mu \mathrm{l}$ at $37^{\circ} \mathrm{C}$. Standard medium (mean $\pm \mathrm{SD}$ of eight experiments), $\mathrm{O}$; medium with $5 \mathrm{mM}$ $\mathrm{MgCl}_{2}$ and $5 \mathrm{mM}$ ATP (mean $\pm \mathrm{SD}$ of eight experiments), $\Delta$; medium with $5 \mathrm{mM}$ ammonium oxalate, $\bullet$; medium with $5 \mathrm{mM}$ ammonium oxalate, $5 \mathrm{mM} \mathrm{MgCl}_{2}$, and $5 \mathrm{mM} \mathrm{ATP,} \triangle$. Ionophore A23187 (5 $\mu \mathrm{M})$ was added to an incubation medium lacking oxalate at $8 \mathrm{~min}$ $(---)$. 
$<1 \mathrm{~min}$ and did not increase thereafter. This base-line uptake was very similar whether or not ammonium oxalate was added. In the presence of both $\mathrm{Mg}$ and $\mathrm{ATP}, \mathrm{Ca}$ uptake was continuous for $\sim 20 \mathrm{~min}$, but the Ca uptake rate decreased after $9 \mathrm{~min}$. Addition of the $\mathrm{Ca}^{+2}$ ionophore $\mathrm{A} 23187(5 \mu \mathrm{M})$ to the podosomes after $8 \mathrm{~min}$ of $\mathrm{Ca}$ uptake initiated a rapid release of $\mathrm{Ca}$ from the loaded podosomes to basal levels, demonstrating thereby that $\mathrm{Ca}$ uptake had occurred against an electrochemical gradient. When ammonium oxalate was added to the incubation medium, Ca uptake continued in a linear fashion for $>20 \mathrm{~min}$, and in some experiments up to $\mathbf{4 0} \mathrm{min}$ (results not shown).

Fig. 2 shows several general characteristics of this Ca transport system. Its activity was proportional to the protein concentration
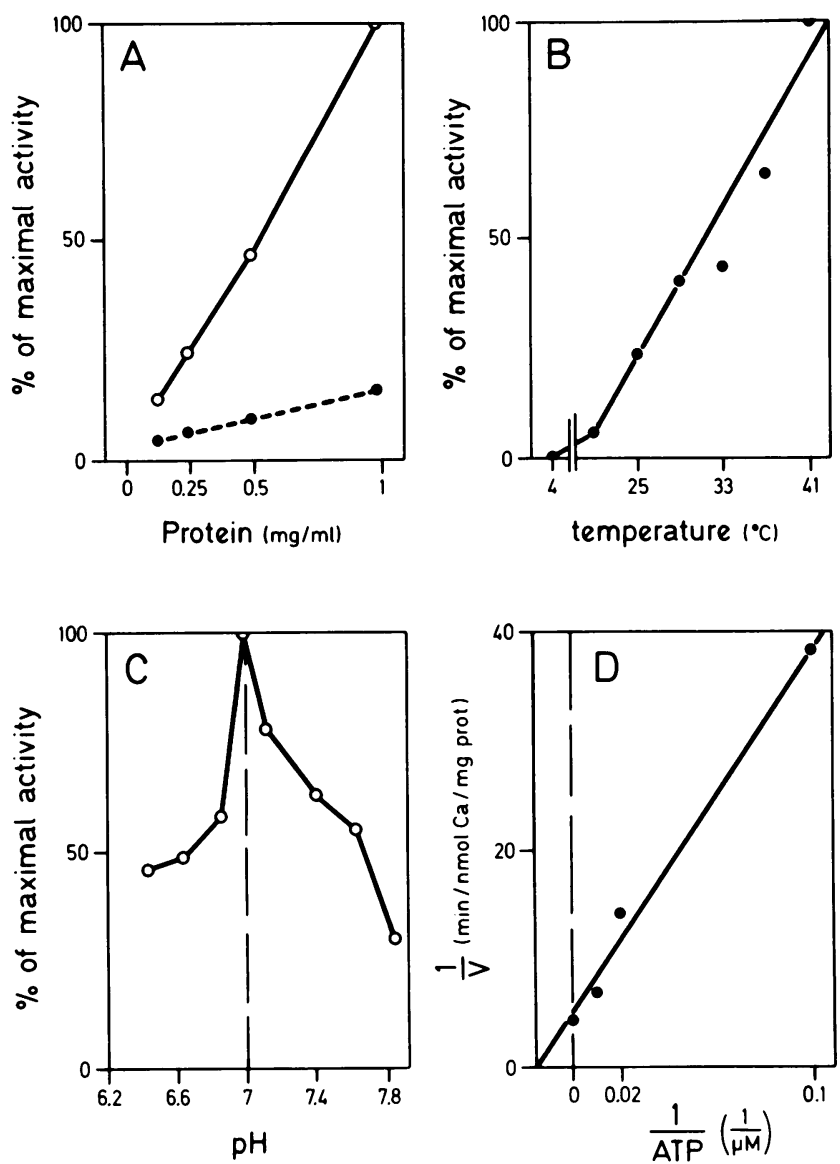

Figure 2. Other characteristics of calcium uptake by podosomes obtained from guinea pig PMN. Ca uptake was performed in the same standard medium as Fig. 1. (A) Ca uptake as a function of protein concentration, in the presence of $(O)$ or without $(\bullet) 5 \mathrm{mM}$ ATP and $5 \mathrm{mM} \mathrm{MgCl}_{2}$. (B) Ca uptake related to temperature of the incubation medium. $(C) \mathrm{Ca}$ uptake related to $\mathrm{pH}$ of incubation medium. The various $\mathrm{pHs}$ were measured in the presence of podosomes at $37^{\circ} \mathrm{C}$. (D) Lineweaver-Burke plot of $K_{\mathrm{m}}$ for ATP in Ca uptake by podosomes. $10 \mathrm{mM} \mathrm{MgCl}$ and variable concentrations of ATP: $0,10,50,100$ and $1,000 \mu \mathrm{M}$. The $K_{\mathrm{m}}$ ATP was $67 \mu \mathrm{M}$ as plotted from this graph. within the range $125-1,000 \mu \mathrm{g}$ protein $/ \mathrm{ml}$. There was no detectable $\mathrm{Ca}$ uptake at $4^{\circ} \mathrm{C}$ and increasing the temperature of the incubation medium from 25 to $41^{\circ} \mathrm{C}$ caused a fourfold increase in $\mathrm{Ca}$ uptake. When the temperature was raised to $100^{\circ} \mathrm{C}$ for $1 \mathrm{~min}, \mathrm{Ca}$ uptake was totally abolished. Optimal $\mathrm{pH}$ of the incubation medium was 7.0, and Ca uptake decreased by $50 \%$ at pH 6.6 and 7.6 (Fig. $2 C$ ). The affinity of the $\mathrm{Ca}$ uptake activity for ATP was determined, as shown in Fig. 2 D, using a Lineweaver-Burke plot. Plotted from this graph, $K_{\mathrm{m}}$ for ATP was near $67 \mu \mathrm{M}$ in the presence of $5 \mathrm{mM} \mathrm{MgCl}_{2}$. Nucleotide requirements were rather specific: ADP promoted a Ca uptake which was $13 \%$ of that obtained with ATP at the same concentration. The other nucleotides tested, i.e., CTP, GTP, ITP, and UTP, did not promote any detectable $\mathrm{Ca}^{+2}$ uptake.

Fig. 3 shows the effect of various free $\mathrm{Ca}$ concentration on uptake by podosomes. Calculated $K_{\mathrm{m}}$ for Ca was $280 \pm 120 \mathrm{nM}$ (range $110 \mathrm{nM}-510 \mathrm{nM}$ ) and $V_{\max } 0.83 \pm 0.26 \mathrm{nmol} \mathrm{Ca} / \mathrm{mg}$ protein/min (mean \pm SD of six experiments). At high free Ca concentration $(\sim 20 \mu \mathrm{M}), \mathrm{Ca}$ uptake rate decreased slightly.

Inhibition of $\mathrm{Ca}$ uptake by sodium orthovanadate is shown in Fig. 4. 50\% inhibition of Ca uptake was obtained with $\sim 1.5$ $M$ vanadate, and $85 \%$ (maximal) inhibition with $\sim 15 \mu \mathrm{M}$.

As shown in Table I, incubation of podosomes with NEM totally abolished $\mathrm{Ca}$ uptake, whereas ouabain, sodium azide, and ruthenium red had no effect. The absence of inhibition by azide and ruthenium red (Table I) excludes a mitochondrial contamination of our preparation. Trifluoperazine $(30 \mu \mathrm{M})$ resulted in $50 \%$ reduction of the Ca uptake. When $100 \mathrm{mM} \mathrm{KCl}$ was substituted by $100 \mathrm{mM} \mathrm{NaCl}$ in the standard medium, $\mathrm{Ca}$ uptake was not modified (Fig. 5). The addition of $80 \mathrm{mM} \mathrm{NaCl}$ or $80 \mathrm{mM} \mathrm{KCl}$ to a standard reaction medium did not affect significantly the time course of $\mathrm{Ca}$ uptake.

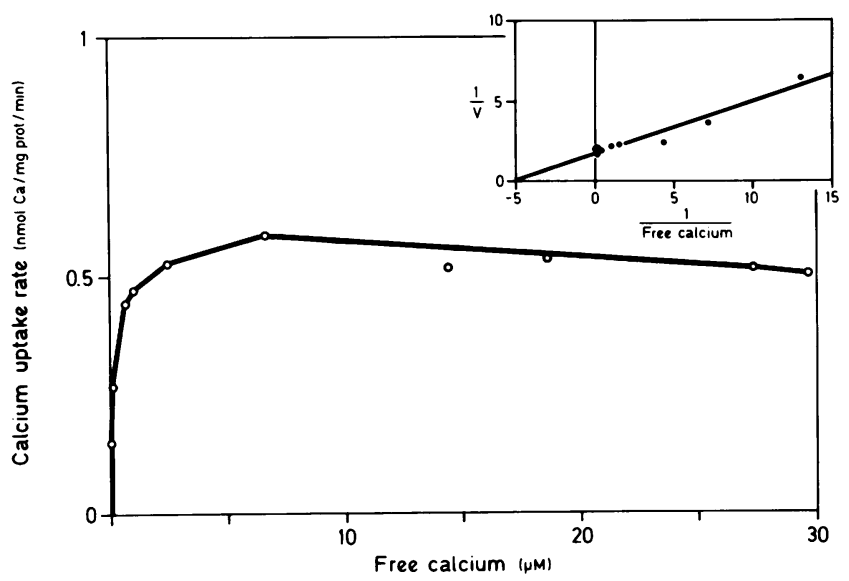

Figure 3. Rate of calcium uptake by podosomes at various free calcium concentrations. The incubation medium is described in the legend of Fig. 1 except that $100 \mu \mathrm{M} \mathrm{CaCl}_{2}$ was added to all tubes with various concentrations of EGTA. Free $\mathrm{Ca}$ concentrations were calculated and measured as described in the text. $K_{\mathrm{m}}$ for $\mathrm{Ca} \cong 190$ $\mathrm{nM}$ and $V_{\max } \cong 0.58 \mathrm{nmol} \mathrm{Ca} / \mathrm{mg}$ protein per min in this experiment. $V$, catalytic rate. 


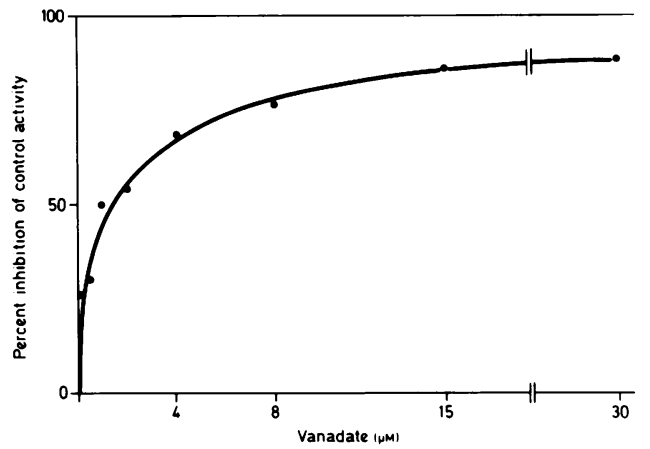

Figure 4. Vanadate inhibition of calcium uptake by podosomes. Ca uptake was initiated by the addition of $2.5 \mathrm{mM}$ ATP. Otherwise the reaction was performed in the same standard medium as Fig. $1.50 \%$ inhibition was obtained with $1.5 \mu \mathrm{M}$ vanadate.

Effect of calmodulin addition to calmodulin-depleted podosomes. Ca uptake by podosomes washed twice with EGTA was decreased by a factor of five when compared with unwashed podosomes (Figs. 1 and 6 for comparison). Podosomes washed twice or more in EGTA became sensitive to the addition of calmodulin, whereas unwashed podosomes did not change their Ca uptake after the addition of calmodulin. Increasing the number of washings beyond two, however, progressively and irreversibly inactivated the Ca pump activity.

When exogenous calmodulin was added to the incubation medium, an increase in $\mathrm{Ca}$ uptake occurred. At calmodulin concentration up to $10 \mu \mathrm{g} / \mathrm{ml}$, and at high free Ca concentrations (free $\mathrm{Ca}=10 \mu \mathrm{M}$ ) a maximal $50 \%$ increase of $\mathrm{Ca}$ uptake could be demonstrated (Fig. 6). Higher calmodulin concentration (60 $\mu \mathrm{g} / \mathrm{ml}$ ) did not produce any further increase of Ca uptake (not shown). Addition of the ionophore A23187 released accumulated $\mathrm{Ca}$ and $\mathrm{Ca}$ content returned to basal levels in all groups.

The stimulatory effect of calmodulin was more evident in the presence of submicromolar free $\mathrm{Ca}$ concentrations (Fig. 7). Fig. 7 shows the effect of various $\mathrm{Ca}$ concentrations on $\mathrm{Ca}$ uptake by EGTA-washed podosomes in the presence or absence of extrinsic calmodulin. The affinity constants of the Ca pump

Table I. Effect of Various Substrates on Calcium Uptake

\begin{tabular}{lcc}
\hline Addition & Concentration & Activity \\
\hline None & & $100 \pm 8$ \\
Ouabain & $2 \mathrm{mM}$ & $97 \pm 9$ \\
Sodium azide & $5 \mathrm{mM}$ & $95 \pm 10$ \\
Ruthenium red & $2 \mu \mathrm{M}$ & $102 \pm 5$ \\
Trifluoperazine & $30 \mu \mathrm{M}$ & $50 \pm 5$ \\
NEM & $1 \mathrm{mM}$ & $0 \pm 0$ \\
& & \\
\hline
\end{tabular}

Incubations and $\mathrm{Ca}$ uptake were performed as described in Methods. Results are averages of triplicates and are expressed as percentage \pm SD of control activity.

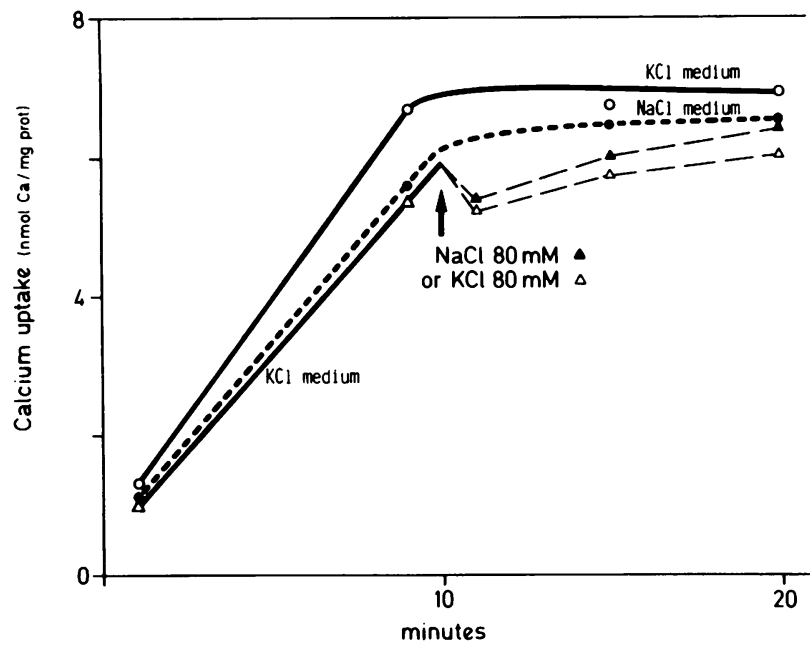

Figure 5. Time course of calcium uptake. Effects of $\mathrm{NaCl}$ substitution for $\mathrm{KCl}$ in standard medium and of the addition of 80 $\mathrm{mM} \mathrm{KCl}$ or $\mathrm{NaCl}$ to $\mathrm{KCl}$ plus imidazole medium. Ca uptake was measured under the same conditions as in Fig. 1, using the same $\mathrm{KCl}$ $100 \mathrm{mM}$ plus imidazole $30 \mathrm{mM}$ buffer $(\mathrm{O})$ or $\mathrm{NaCl} 100 \mathrm{mM}$ plus imidazole $30 \mathrm{mM}$ buffer $(\bullet) .80 \mathrm{mM} \mathrm{NaCl}(\Delta)$ or $\mathrm{KCl}(\Delta---\Delta)$ was added at $10 \mathrm{~min}$ to $\mathrm{KCl}$ plus imidazole buffer $(\Delta-\Delta)$.

in the absence or presence of calmodulin were as follows: The $K_{\mathrm{m}}$ for Ca was $2.07 \mu \mathrm{M}$ and the $V_{\max } 0.3 \mathrm{nmol} \mathrm{Ca} / \mathrm{mg}$ protein per $\min$ in the calmodulin-depleted podosomes. When calmodulin $(10 \mu \mathrm{g} / \mathrm{ml})$ was added, the affinity for $\mathrm{Ca}$ increased

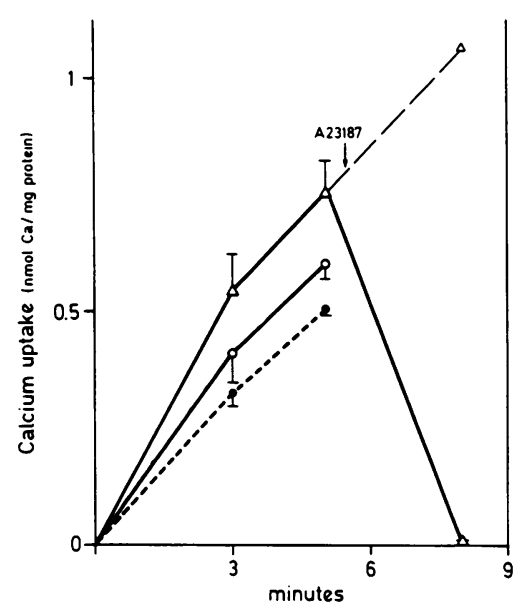

Figure 6. Effect of various doses of calmodulin on the calcium uptake of EGTA-washed podosomes. Podosomes were incubated 5 min at room temperature with calmodulin $5 \mu \mathrm{g} / \mathrm{ml}(\Delta) ; 0.5 \mu \mathrm{g} / \mathrm{ml}$ $(O)$; or without calmodulin $(\bullet)$. Results are expressed as means \pm SD of three experiments using the same membrane preparation. Ionophore A23187 $(5 \mu \mathrm{M})$ in DMSO was added to each experiment and released $\mathrm{Ca}$ to basal levels (shown only for the experiment with 5 $\mu \mathrm{g} / \mathrm{ml}$ calmodulin). Addition of the same volume DMSO (- - ) without $\mathrm{A} 23187$ did not affect $\mathrm{Ca}$ uptake nor induce $\mathrm{Ca}$ release from podosomes. 


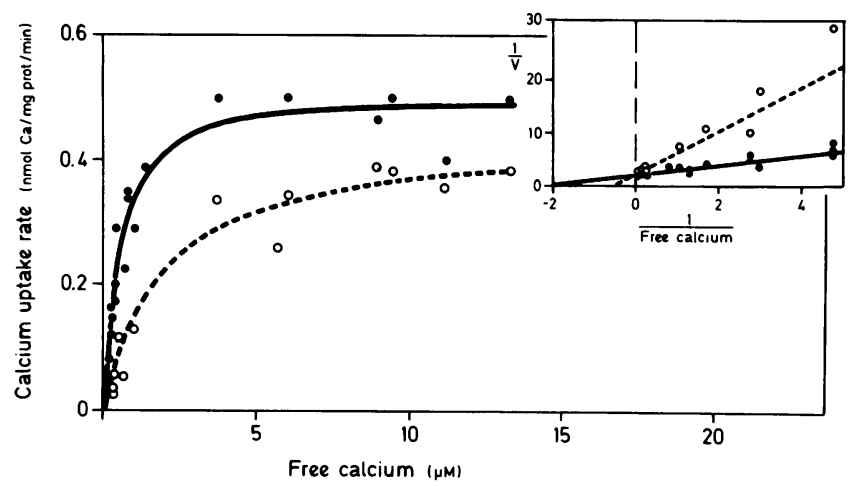

Figure 7. Effect of calmodulin on calcium uptake rate by EGTAwashed podosomes at various free calcium concentrations (Lineweaver-Burke plot in inset). EGTA-washed podosomes were incubated for $5 \mathrm{~min}$ at room temperature with $(\Theta)$ or without $(O) 10$ $\mu \mathrm{g} / \mathrm{ml}$ calmodulin. The incubation medium is described in the legend of Fig. 1 except that $\mathrm{CaCl}_{2} 100 \mu \mathrm{M}$ was added to all tubes with various concentrations of EGTA. Free Ca concentrations were determined as described in the text. The average of duplicates is shown.

$\left(K_{\mathrm{m}}=0.55 \mu \mathrm{M}\right)$ concurrently with the $V_{\max }(0.5 \mathrm{nmol} \mathrm{Ca} / \mathrm{mg}$ protein per min), suggesting that the calmodulin effect is mediated by increasing the affinity of the pump for $\mathrm{Ca}$. Under these conditions, calmodulin also increased the $V_{\max }$ of the $\mathrm{Ca}$ pump.

Calcium uptake by human podosomes. Human podosomes displayed a $\mathrm{Ca}$ transport similar to guinea pig podosomes. The uptake of $\mathrm{Ca}$ was dependent on the presence of $\mathrm{Mg}$ and ATP with a similar affinity constant for $\mathrm{Ca}$ but with a lower specific activity (Table II). Ionophore A23187 $(5 \mu \mathrm{M})$ released Ca from loaded podosomes until basal levels were achieved. The $\mathrm{Ca}$ pump activity persisted longer in the presence of ammonium oxalate, ADP promoted $\sim 30 \%$ of the activity, measured in the presence of ATP, whereas UTP, CTP, and GTP were inactive. The system was not inhibited by azide or ruthenium red. The

Table II. Characteristics of Calcium Pump Activity in Podosomes Obtained from Human PMN

\begin{tabular}{ll}
\hline Additions & Activity $\left(K_{\mathrm{m}} \mathrm{Ca}^{2+}, 350 \mathrm{nM}\right)$ \\
\hline & $n m o l \mathrm{Ca}^{2+} / m g$ protein per min \\
None & $0.12 \pm 0.02$ \\
ADP $(5 \mathrm{mM})$ & $0.04 \pm 0.01$ \\
CTP, GTP, UTP $(5 \mathrm{mM})$ & 0.00 \\
Azide $(5 \mathrm{mM})$ & $0.11 \pm 0.03$ \\
Ruthenium red $(2 \mu \mathrm{M})$ & $0.12 \pm 0.03$ \\
NEM $(1 \mathrm{mM})$ & 0.00 \\
Trypsin $(1 \mathrm{mg} / \mathrm{ml})$ & 0.00
\end{tabular}
* Results of a typical experiment performed on the same day with the
same membrane preparation. Average $\pm S D$ of triplicates. activity was abolished by preincubation of podosomes in NEM or trypsin under similar conditions as described for guinea pig podosomes (Table II).

Arrangement of the calcium pump system in the plasma membrane of neutrophils. To obtain an estimate of the percentage of inside-out vesicles in our preparation of podosomes, 5 '-nucleotidase activity, an ectoenzyme of guinea pig granulocytes, was measured in the presence and absence of Triton X100. The calculated proportion of inside-out vesicles in the podosomes preparation was $40 \pm 5 \%$ (average \pm SD of triplicate determinations in three different preparations).

We were also able to demonstrate a Ca pump activity in phagocytic vesicles, i.e., a homogenous population of insideout plasma membrane vesicles from guinea pig PMN. This activity was $\mathrm{Mg}$ - and $\mathrm{ATP}$-dependent and pumped $\mathrm{Ca}$ at a rate of $0.7 \mathrm{nmol} \mathrm{Ca} / \mathrm{mg}$ protein per min in standard medium containing $25 \mu \mathrm{M} \mathrm{Ca}$. Ca uptake was abolished by pretreating the vesicles with trypsin and pCMBS (Table III). Inactivation of Ca uptake was also observed when podosomes were pretreated with pCMBS and trypsin. By contrast, no effect was seen when whole cells were treated with trypsin or pCMBS before preparation of podosomes. These results are consistent with an asymetrical structure of the Ca pump across the plasma membrane: a proteic moiety and sulfhydric component being exposed at the cytoplasmic surface.

\section{Discussion}

The present findings demonstrate the presence of an energydependent $\mathrm{Ca}$ pump in the plasma membrane of neutrophils, capable of transporting $\mathrm{Ca}$ against an electrochemical gradient from the inside of the cell into the extracellular medium. This active transport is an important attribute of plasma membrane ATPases, which have to displace $\mathrm{Ca}$ across a 10,000-fold gradient (35). The physiological importance of the Ca pump described is suggested by its optimal activity at free $\mathrm{Ca}$ concentrations

Table III. Effect of Trypsin and pCMBS on Ca Pump Activity of Podosomes and Phagocytic Vesicles

\begin{tabular}{lccc}
\hline & $\begin{array}{l}\text { Phagocytic } \\
\text { vesicles }\end{array}$ & Podosomes & Whole PMN \\
\hline & $\%$ & $\%$ & $\%$ \\
None (control activity) & $100 \pm 8$ & $100 \pm 6$ & $100 \pm 8$ \\
Trypsin & $0 \pm 0$ & $0 \pm 0$ & $93 \pm 4$ \\
Trypsin plus SBTI & not done & $110 \pm 6$ & not done \\
SBTI & not done & $106 \pm 2$ & not done \\
pCMBS & $0 \pm 0$ & $0 \pm 0$ & $100 \pm 6$ \\
& & & \\
\hline
\end{tabular}

Phagocytic vesicles, podosomes, or whole PMN were incubated either in 0.34 sucrose- $30 \mathrm{mM}$ imidazole, $\mathrm{pH} \mathrm{7,} \mathrm{without} \mathrm{any} \mathrm{additive} \mathrm{or} \mathrm{with}$ one of the following compounds: trypsin $(1 \mathrm{mg} / \mathrm{ml}) ; \operatorname{trypsin}(1 \mathrm{mg} / \mathrm{ml})$ plus SBTI $(1 \mathrm{mg} / \mathrm{ml})$; SBTI $(1 \mathrm{mg} / \mathrm{ml})$; or pCMBS $(50 \mu \mathrm{M})$. Incubations lasted for $5 \mathrm{~min}$ except for pCMBS $(30 \mathrm{~min})$. Results are averages of triplicates and are expressed as percentages \pm SD of control activity. 
encountered within the cytoplasm: free $\mathrm{Ca}$ concentrations in neutrophils were recently measured, and resting values of 100 $200 \mathrm{nM}$ were observed (36). These values increased to micromolar levels upon chemotactic peptide stimulation. Because of its high affinity for $\mathrm{Ca}$, this $\mathrm{Ca}$ pump is able to function at physiological free $\mathrm{Ca}$ concentrations in resting and stimulated neutrophils.

In recent years, high affinity Ca-ATPases as well as ATP and Ca-dependent phosphorylation processes have been shown to be associated with the plasma membrane of neutrophils (3739). The large number of nonspecific ATPases and kinases present in these cells, however, has precluded the establishment of a correlation of these activities with $\mathrm{Ca}$ transport. A Ca pump in phagocytic vesicles of rabbit neutrophils has recently been described (40). The reported $K_{\mathrm{m}}$ for Ca was $2.8 \mu \mathrm{M}$, a value which is considerable higher than the $K_{\mathrm{m}}$ values obtained in other nucleated cells (i.e., macrophages: $K_{\mathrm{m}} \mathrm{Ca}=480 \pm 10 \mathrm{nM}$; heart sarcolemma: $\left.K_{\mathrm{m}} \mathrm{Ca}=300 \pm 200 \mathrm{nM}\right)(17,41-43)$ and well above the presumed resting cytosolic free $\mathrm{Ca}$ levels in rabbit PMN. An analysis of their results indicates, however, a twocomponent $\mathrm{Ca}$ uptake: One of the components was saturable with a low $K_{\mathrm{m}}$, while the other did not saturate in the range of $\mathrm{Ca}$ concentrations used.

In our system, the maximal $\mathrm{Ca}$ uptake activity occurred at $\mathrm{pH} \mathrm{7,} \mathrm{which} \mathrm{is} \mathrm{the} \mathrm{presumed} \mathrm{cytosolic} \mathrm{pH}$ in resting neutrophils. The pump was active at low ATP concentrations $\left(K_{\mathrm{m}}, 67 \mu \mathrm{M}\right)$, indicating that this nucleotide is not a regulator of the pump under physiologic conditions. The nucleotide specificity was similar to that described for the Ca pump of the macrophage plasma membrane, where only ATP was effective, with ADP promoting only partial Ca uptake (17).

Low concentrations of vanadate, such as those used in this study, have proven to be a useful tool for the inhibition of the Ca-ATPase activity of plasma membrane vesicles (44). It has been used in heart tissue to distinguish plasma membrane activity from that of contaminating sarcoplasmic reticulum vesicles (41). Recently, Varecka and Carafoli (45), using $0.5 \mathrm{mM}$ vanadate, have shown a decreased ${ }^{45} \mathrm{Ca}$ efflux from erythrocytes and suggested that this compound led to high levels of intracellular $\mathrm{Ca}$ by Ca-ATPase inhibition.

In addition to the $\mathrm{Ca}$ transport mediated by the ATPases, several plasma membranes also possess a $\mathrm{Na} / \mathrm{Ca}$ exchange system. Experiments performed in $\mathrm{NaCl}$-containing medium, or the addition of $\mathrm{NaCl}$ to $\mathrm{KCl}$-containing medium after several minutes of $\mathrm{Ca}$ uptake have allowed detection of such exchanges in other systems (46). Our negative results militate against such a system in the plasma membrane of guinea pig neutrophils.

By measuring 5'-nucleotidase activity, an ectoenzyme of guinea pig PMN, we were able to estimate the proportion of inside-out vesicles in the podosome preparation. A similar value of $\sim 40 \%$ can be calculated from the results obtained by Cohen et al. (47) during Triton X-100 activation of the NADPH-dependent superoxide-generating system, a marker of the inner surface of the plasma membrane in digitonin-activated guinea pig podosomes. Preincubation with trypsin or pCMBS led to an inhibition of $\mathrm{Ca}$ uptake by phagocytic vesicles and podosomes, but not in whole cells, suggesting that the Ca pump presents a susceptible protein moiety and a sulfhydryl radical at the cytoplasmic side of the plasma membrane (i.e., at the outer side of the phagocytic vesicle).

An influence of calmodulin on several plasma membrane Ca-ATPases has been shown recently $(17,41,43,48)$. This ubiquitous protein is a modulator of many $\mathrm{Ca}$-dependent processes (49). Its functions can be explored by the use of phenothiazines such as trifluoperazine at appropriately low concentrations $(<50 \mu \mathrm{M})$, when calmodulin antagonism occurs (4951). In our hands, trifluoperazine $(30 \mu \mathrm{M})$ inhibited Ca pump activity, suggesting the involvement of calmodulin in this system. Alternatively, recent studies have shown that trifluoperazine inhibited purified Ca-ATPase that had been incorporated into liposomes, thus indicating a direct effect on the Ca pump (52). In our system, podosomes did not respond to extrinsically added bovine brain calmodulin, unless they had been washed previously with EGTA. On the other hand, depletion of calmodulin from the podosomes was limited by several technical problems, more than two EGTA washings drastically reducing Ca uptake, indicating some kind of membrane damage. After two EGTA washings, however, podosomes retained a satisfactory residual Ca pump activity and the stimulating effect of exogenous calmodulin could be demonstrated. Under these conditions calmodulin shifted the $\mathrm{Ca}$ pump to a higher affinity state for $\mathrm{Ca}$, and enhanced the maximal velocity of this $\mathrm{Ca}$ transport system. These results are in accord with other observations made with sarcolemma and erythrocyte membranes $(41,53)$.

Our present findings allow us to speculate that the Ca pump described could play a major role in the control of movement in the neutrophil. There is indeed extensive experimental evidence that movement in ameboid cells depends on a Ca-dependent gel-sol transformation in the peripheral cytoplasm (12, 54). Contact of an opsonized particle with specific surface neutrophil receptors presumably raises the cytosolic $\mathrm{Ca}$, creating solation of the peripheral cytoplasm, which in turn allows free access of granules to the plasma membrane, i.e., degranulation and stimulation of the superoxide generating system (55). Secondary to this $\mathrm{Ca}$ rise, $\mathrm{Ca}$ pump stimulation by calmodulin binding and other receptor-mediated events, such as pump phosphorylation, may decrease local cytosolic Ca concentrations to levels where gelation occurs, with the formation of a pseudopod that would progressively surround its prey.

Although the exact sequence of calcium changes in the peripheral cytoplasm during phagocytosis remains to be shown, it is very likely that the calcium pump present in the plasma membrane of neutrophils plays an important role in the regulation of intracellular calcium homeostasis of the resting or stimulated neutrophil.

\section{Acknowledgments}

We gratefully acknowledge Mrs. E. Huggler for taking care of the guinea pigs and her skillful technical help, Mrs. A. Dall'aglio for typing the manuscript, and Philip Halban and Elisabeth Trimble for reviewing the manuscript. 
This work was supported in part by grant Nos. 3.869-0.81, 3.8691.81, and 3.986-0.82 from the Swiss Research Foundation.

\section{References}

1. Stossel, T. P. 1974. Phagocytosis. N. Engl. J. Med. 291:717-723, 774-780, 833-839.

2. Babior, B. M. 1978. Oxygen-dependent microbial killing by phagocytes. N. Engl. J. Med. 298:659-668, 721-725.

3. Snyderman, R., and E. J. Goetzl. 1981. Molecular and cellular mechanisms of leukocyte chemotaxis. Science (Wash. DC). 213:830837.

4. Stossel, T. P. 1973. Quantitative studies of phagocytosis: kinetic effects of cations and heat-labile opsonin. J. Cell Biol. 58:346-356.

5. Smolen, J. E., H. M. Korchak, and G. Weissmann. 1981. The roles of extracellular and intracellular calcium in lysosomal enzyme release and superoxide anion generation by human neutrophils. Biochim. Biophys. Acta. 677:512-520.

6. Cockcroft, S., J. P. Bennett, and B. D. Gomperts. 1981. The dependence on $\mathrm{Ca}^{2+}$ of phosphatidylinositol breakdown and enzyme secretion in rabbit neutrophils stimulated by formylmethionyl-leucylphenylalanine or ionomycin. Biochem. J. 200:501-508.

7. Romeo, D., G. Zabucchi, N. Miani, and F. Rossi. 1975. Ion movement across leukocyte plasma membrane and excitation of their metabolism. Nature (Lond.). 253:542-544.

8. Kessler, F. K., E. M. Goodell, and R. A. Carchman. 1980. Perturbation of the phagocytic response in $P 388 \mathrm{D}_{1}$ cultured macrophages by agents altering cell calcium. Cell Calcium. 1:181-194.

9. Trotter, J. A., and R. L. Quintana. 1981. Inhibition of macrophage spreading by antagonists of cellular calcium. FEBS (Fed. Eur. Biochem. Soc.) Lett. 129:29-32.

10. Smith, R. J., and S. S. Iden. 1981. Modulation of human neutrophil superoxide anion generation by the calcium antagonist $8-(\mathrm{N}, \mathrm{N}$ diethylamino)-octyl-(3,4,5-trimethoxy)benzoate hydrochloride. J. $R e$ ticuloendothel. Soc. 29:215-225.

11. Smith, R. J., B. J. Bowman, and S. S. Iden. 1981. Effects of trifluoperazine on human neutrophil function. Immunology. 44:677684.

12. Yin, H. L., and T. P. Stossel. 1979. Control of cytoplasmic actin gel-sol transformation by gelsolin, a calcium-dependent regulatory protein. Nature (Lond.). 281:583-586.

13. Cheung, W. Y. 1980. Calmodulin plays a pivotal role in cellular regulation. Science (Wash. DC). 207:19-27.

14. Petroski, R. J., P. H. Naccache, E. L. Becker, and R. I. Sa'afi. 1979. Effect of chemotactic factors on calcium levels of rabbit neutrophils. Am. J. Physiol. 237:C43-C49.

15. Mottola, C., and D. Romeo. 1982. Calcium movement and membrane potential changes in the early phase of neutrophil activation by phorbol myristate acetate: a study with ion-selective electrodes. $J$. Cell Biol. 93:129-134.

16. Cohen, H. J., and M. E. Cholvaniec. 1978. Superoxide production by digitonin-stimulated guinea pig granulocytes. The effects of $N$-ethylmaleimide, divalent cations, and glycolytic and mitochondrial inhibitors on the activation of the superoxide generating system. J. Clin. Invest. 61:1088-1096.

17. Lew, D. P., and T. P. Stossel. 1980. Calcium transport by macrophage plasma membranes. J. Biol. Chem. 255:5841-5846.

18. Babior, B. M., and H. J. Cohen. 1981. Measurement of neutrophil function: phagocytosis, degranulation, the respiratory burst and bacterial killing. In Leukocyte Function. Cline, editor. Churchill Livingston, Inc., New York. 1-38.
19. Böyum, A. 1968. Isolation of mononuclear cells and granulocytes from human blood. Scand. J. Clin. Lab. Invest. 97(Suppl.):77-89.

20. Cohen, H. J., M. E. Chovaniec, and W. A. Davies. 1980. Activation of the guinea pig granulocyte. NAD(P)H-dependent superoxide generating enzyme: localization in a plasma membrane enriched particle and kinetics of activation. Blood. 55:355-363.

21. Lew, P. D., F. S. Southwick. T. P. Stossel, J. C. Within, E. Simons, and H. J. Cohen. 1981. A variant of chronic granulomatous disease: deficient oxidative metabolism due to a low-affinity NADPH oxidase. N. Engl. J. Med. 305:1329-1333.

22. Newburger, P. E., M. E. Chovaniec, and H. J. Cohen. 1980. Activity and activation of the granulocyte superoxide-generating system. Blood. 55:85-92.

23. DePierre, J. W., and M. L. Karnovsky. 1974. Ecto-enzymes of the guinea pig polymorphonuclear leukocyte. J. Biol. Chem. 249:71117129.

24. Waisman, D. M., J. M. Gimble, D. B. P. Goodman, and H. Rasmussen. 1981. Studies of the $\mathrm{Ca}^{2+}$ transport mechanism of human erythrocyte inside-out plasma membrane vesicles. J. Biol. Chem. 256:409-414.

25. Stossel, T. P., T. D. Pollard, R. J. Masson, and M. Vaughan. 1971. Isolation and properties of phagocytic vesicles from polymorphonuclear leukocytes. J. Clin. Invest. 50:1745-1757.

26. Stossel, T. P., R. J. Field, J. D. Gitlin, C. A. Alper, and F. S. Rosen. 1975. The opsonic fragment of the third component of human complement (C3). J. Exp. Med. 141:1329-1347.

27. Amrein, P. C., and T. P. Stossel. 1980. Prevention of degradation of human polymorphonuclear leukocyte proteins by diisopropylfluorophosphate. Blood. 56:442-447.

28. Perrin, D. D., and I. G. Sayce. 1967. Computer calculation of equilibrium concentrations in mixtures of metal ions and complexing species. Talanta. 14:833-842.

29. Simon, W., D. Amman, M. Oehme, and W. E. Morf. 1978. Calcium-selective electrodes. Ann. NY Acad. Sci. 307:52-70.

30. Prentki, M., M. Crettaz, and B. Jeanrenaud. 1981. Role of microtubules in insulin and glucagon stimulation of amino acid transport in isolated rat hepatocytes. J. Biol. Chem. 256:4336-4340.

31. Morcos, N. C. 1982. Localization of $\left(\mathrm{Ca}^{2+}+\mathrm{Mg}^{2+}\right)$-ATPase, $\mathrm{Ca}^{2+}$ pump and other ATPase activities in cardiac sarcolemma. Biochim. Biophys. Acta. 688:747-756.

32. Lowry, O., N. J. Rosebrough, A. L. Farr, and R. J. Randall. 1951. Protein measurement with the Folin phenol reagent. J. Biol. Chem. 193:265-275.

33. Lew, P. D., and T. P. Stossel. 1981. Effect of calcium on superoxide production by phagocytic vesicles from rabbit alveolar macrophages. J. Clin. Invest. 67:1-9.

34. Farrance, M. L., and F. F. Vincenzi. 1977. Enhancement of $\left(\mathrm{Ca}^{2+}+\mathrm{Mg}^{2+}\right)$-ATP-ase activity of human erythrocyte membranes by hemolysis in isosmotic imidazole buffer. II. Dependence on calcium and a cytoplasmic activator. Biochim. Biophys. Acta. 471:59-66.

35. Schatzmann, H. J., H. Buergin, S. Luterbacher, J. Stieger, A. Wuetrich, and J. P. Rossi. 1982. How to keep cellular calcium low. The red cell as an example. INSERM (Inst. Natl. Sante Rech. Med.) Symp. 6:13-25.

36. Lagast, H., T. Pozzan, P. D. Lew, and F. A. Waldvogel. 1983 Phorbol myristate acetate stimulates the plasma membrane calcium pump of human and guinea pig neutrophils without raising cytosolic free calcium. Clin. Research. 31(2):410A. (Abstr.)

37. Jackovski, S., K. Petro, and R. I. Sha'afi. 1979. A Ca ${ }^{2+}$-stimulated ATPase activity in rabbit neutrophil membranes. Biochim. Biophys. Acta. 558:348-352. 
38. Schneider, C., C Mottola, and D. Romeo. 1979. Calcium-ion dependent adenosine triphosphate activity and plasma-membrane phosphorylation in the human neutrophil. Biochem. J. 182:655-660.

39. Gennero, R., C. Mottola, C. Schneider, and D. Romeo. 1979. $\mathrm{Ca}^{2+}$-dependent ATPase activity of alveolar macrophage plasma membrane. Biochim. Biophys. Acta. 567:238-246.

40. Volpi, M., P. H. Naccache, and R. I. Sha'afi. 1983. Calcium transport in inside-out membrane vesicles prepared from rabbit neutrophils. J. Biol. Chem. 258:4153-4158.

41. Caroni, P., and E. Carafoli. 1981. The $\mathrm{Ca}^{2+}$-pumping ATPase of heart sarcolemma. J. Biol. Chem. 256:3263-3270.

42. Kraus-Friedmann, N., J. Biber, H. Murer, and E. Carafoli. 1982. Calcium uptake in isolated hepatic plasma-membrane vesicles. Eur. $J$. Biochem. 129:7-12.

43. Scully, S. P., G. B. Segel, and M. A. Lichtman. 1982. Plasma membrane vesicles prepared from unadhered monocytes: characterization of calcium transport and the calcium ATPase. Cell Calcium. 3:515530.

44. Simons, T. J. B. 1979. Vanadate-a new tool for biologists. Nature (Lond.). 281:337-338.

45. Varecka, L., and E. Carafoli. 1982. Vanadate-induced movements of $\mathrm{Ca}^{2+}$ and $\mathrm{K}^{+}$in human red blood cells. J. Biol. Chem. 257:74147421 .

46. Caroni, P., and E. Carafoli. 1980. An ATP-dependent $\mathrm{Ca}^{2+}$. pumping system in dog heart sarcolemma. Nature (Lond.). 283:765768.

47. Cohen, H. J., M. E. Chovaniec, and W. E. Davies. 1980. Localization and activation of the guinea pig granulocyte NAD(P)H-de- pendent superoxide generating enzyme: kinetics of activation and effect of detergents. In Biological and Clinical Aspects of Superoxide and Superoxide Dismutase. W. H. Bannister and J. V. Bannister, editors. Elsevier/North Holland, Amsterdam. 180-192.

48. Larsen, F. L., and F. F. Vincenzi. 1979. Calcium transport across the plasma membrane: stimulation by calmodulin. Science (Wash. DC). 204:306-309.

49. Scharff, O. 1981. Calmodulin and its role in cellular activation. Cell Calcium. 2:1-27.

50. Gietzen, K., A. Mangard, and H. Bader. 1980. Inhibition of human erythrocyte $\mathrm{Ca}^{++}$-transport ATPase by phenothiazines and butyrophenones. Biochem. Biophys. Res. Commun. 94:674-681.

51. Vincenzi, F. F. 1981. Calmodulin pharmacology. Cell Calcium. 2:387-409.

52. Vincenzi, F. F., E. S. Adunyah, V. Niggli, and E. Carafoli. 1982. Purified red blood cell $\mathrm{Ca}^{2+}$-pump ATPase: evidence for direct inhibition by presumed anti-calmodulin drugs in the absence of calmodulin. Cell Calcium. 3:545-559.

53. Scharff, O., and B. Foder. 1978. Reversible shift between two states of $\mathrm{Ca}^{2+}$-ATPase in human erythrocytes mediated by $\mathrm{Ca}^{2+}$ and a membrane bound activator. Biochim. Biophys. Acta 509:67-77.

54. Yin, H. L., J. H. Albrecht, and A. Fattoum. 1981. Identification of gelsolin, a $\mathrm{Ca}^{2+}$-dependent regulatory protein of actin gel-sol transformation, and its intracellular distribution in a variety of cells and tissues. J. Cell Biol. 91:901-906.

55. Southwick, F. S., and T. P. Stossel. 1983. Contractile proteins in leukocyte function. Semin. Hematol. 20:305-321. 